\title{
Dampak Positif dan Negatif Pembelajaran Jarak Jauh di Masa Pandemi COVID-19
}

\author{
Ni Nyoman Serma Adi ${ }^{1 *}$, Dewa Nyoman Oka ${ }^{2}$, Ni Made Serma Wati ${ }^{3}$ iD \\ 1,2,3 Universitas Pendidikan Ganesha, Singaraja, Indonesia \\ *Corresponding author: serma88@gmail.com
}

\begin{abstract}
Abstrak
Pandemi COVID-19 memberikan dampak terhadap berbagai bidang termasuk pendidikan. Proses pembelajaran beralih dari pembelajaran tatap muka menjadi pembelajaran jarak jauh. Penelitian ini bertujuan untuk menganalisis dampak positif dan negatif pembelajaran jarak jauh di masa pandemic COVID-19. Jenis penelitian adalah kualitatif. Populasi penelitian ini adalah semua mahasiswa di universitas. Populasi penelitian berjumlah 10 mahasiswa. Pengambilan sampel dalam penelitian ini dilakukan dengan cara random sampling dengan jumlah sampel 5. Instrumen pengumpulan data menggunakan wawacara menggunakan pedoman wawancara, teknik analisis data menggunakan analisis kualitatif. Hasil penelitian menunjukkan bahwa terdapat dampak negative pembelajaran jarak jauh yaitu jaringan tidak memadai, mahasiswa kurang paham dengan materi pembelajaran, mahasiswa merasa kurang semangat mengikuti pembelajaran daring, keterbatasan fasilitas dalam pembelajaran daring menyulitkan mahasiswa dan kuota internet mahal. Dampak positif dari pembelajaran jarak jauh yaitu pembelajaran daring lebih parktis dan santai. penyampaian informasi lebih cepat dan bisa menjangkau banyak mahasiswa, siswa lebih tertarik dalam mengerjakan tugas, dosen dan siswa memperoleh pengalaman baru terkait pembelajaran daring. Maka, dapat disimpukan bahwa terdapat dampak positif dan negatif pembelajaran jarak jauh di masa pandemic COVID-19.
\end{abstract}

Kata kunci: Pandemi COVID-19, Pembelajaran Jarak Jauh

\section{Abstract}

The COVID-19 pandemic has an impact on various fields including education. The learning process shifts from face-to-face learning to distance learning. This study aims to analyze the positive and negative impacts of distance learning during the COVID-19 pandemic. This type of research is qualitative. The population of this study were all students at the university. The study population was 10 students. Sampling in this study was carried out by means of random sampling with a sample size of 5. The data collection instrument used interview guides, data analysis techniques included simple correlation and multiple correlation. The results showed that there was a negative impact of distance learning, namely inadequate networks, students lacking understanding of learning materials, students feeling less enthusiastic about participating in online learning, limited facilities in online learning made it difficult for students and expensive internet quotas. The positive impact of distance learning is that online learning is more practical and relaxed. delivery of information is faster and can reach many students, students are more interested in doing assignments, lecturers and students gain new experiences related to online learning. So, it can be concluded that there are positive and negative impacts of distance learning during the COVID-19 pandemic.

Keywords: COVID-19 Pandemic., Distance Learning

$\begin{array}{lll}\text { History: } & & \text { Publisher: Undiksha Press } \\ \text { Received } & : \text {. Januari } 2021 & \text { Licensed: This work is licensed under } \\ \text { Revised } & : 5 \text { Februari } 2021 & \text { a Creative Commons Attribution 4.0 License } \\ \text { Accepted } & : \text { : Maret } 2021 & \text { CC C) } \\ \text { Published } & : 25 \text { Maret } 2021 & \end{array}$

\section{Pendahuluan}

Corona virus merupakan kelompok besar virus yang menyebabkan penyakit dan menimbulkan gejala yang ringan sampai berat (Dewi, 2020; Setiawan, 2020). WHO menyatakan virus COVID-19 menjadi Darurat Kesehatan Masyarakat yang menjadi perhatian Internasional (Sohrabi, et al, 2020; Talevi et al., 2020). Pada bulan Maret 2020 
virus ini juga menyebar di Indonesia. Di Indonesia penyebaran virus COVID-19 memberikan dampak pada berbagai bidang dan meningkatnya angka kematian masyarakat yang positif terkena COVID-19 (Purwanto, 2020). Munculnya virus COVID-19 memberikan dampak terhadap pendidikan. Salah satu upaya menghentikan penyebaran COVID-19 bagi dunia pendidikan, pemerintah mengeluarkan kebijakan yaitu menerapkan proses belajar dari rumah pada berbagai jenjang pendidikan. Adanya penutupan sekolah mengakibatkan peserta didik tidak dapat berinteraksi dengan teman-temannya, dan guru (Nurkholis, 2020). Masa COVID19 mengharuskan pembelajaran tetap berlangsung agar pendidikan terjamin, sehingga pembelajaran dapat dilakukan melalui pembelajaran daring.

Pembelajaran daring merupakan sebuah inovasi pendidikan yang melibatkan teknologi informasi dalam pembelajaran. Pembelajaran Daring dapat diselenggarakan melalui jejaring web dengan jumlah partisipan tanpa batas menggunakan berbagai media teknologi (Putria, 2020; Rigianti, 2020). Pembelajaran daring dapat menciptakan pembelajaran yang efektif serta nyaman bagi peserta didik di tengah pandemi COVID-19 (Herliandry, Devi ., 2020; Zhang et al., 2020). Selain itu, pembelajaran daring bertujuan untuk memenuhi standard pendidikan melalui pemanfaatan teknologi informasi agar saling terhubung antara siswa dan guru, sehingga melalui pemanfaatan teknologi tersebut proses belajar mengajar bisa tetap dilaksanakan dengan baik.

Kenyataannya, pembelajaran daring masih menimbulkan permasalahan. Pembelajaran daring mengakibatkan pergeseran peran antara guru dan orang tua selama pembelajaran daring (Khurriyati et al., 2021). Penyampaian materi secara daring tidak bisa dipahami oleh semua peserta didik. Selain itu, guru mengalami kesulitan dalam mengontrol suasana belajar, hal ini disebabkan keterbatasan dalam ruang virtual (Asmuni, 2020; Fifit Humairoh, Achmad Supriyanto, 2016). Keterbatasan penguasaan teknologi informasi dialami oleh guru dan peserta didik, hal ini dpat dilihat dari guru-guru yang tidak mampu menggunakan berbagai media pembelajaran daring. Selain itu, perangkat teknologi yang mahal juga menjadi permasalahan dalam pelaksanaan pembelajaran daring (Krisdiana et al., 2014; Maria Kristina Ota, Ana Maria Gadi Djou, 2021; Pakpahan \& Fitriani, 2020).

Banyak penelitian yang dilakukan selama pembelajaran daring. Pembelajaran daring di SD dapat terlaksana dengan cukup baik, hal ini terlaksana apabila adanya kerjasama antara kepala sekolah, guru, dan orang tua dalam pelaksanaan belajar dari rumah (Dewi, 2020). Efektivitas pembelajaran daring pada mata kuliah Pendidikan Agama Islam dalam situasi pandemi Covid-19 masuk dalam kategori baik (Alvianto, 2020). Pembelajaran media daring di SMPIT dapat berjalan dengan baik, namun guru dan siswa tetap mengalami kesulitan dalam berinteraksi dan mengakses situs pembelajaran diinternet (Sofralda, Suci \& Atika Latifa, 2019). Temuan lain menyatakan pelaksanaan pembelajaran daring dikatakan kurang efektif karena memiliki beragam problematika yang dialami guru, peserta didik, dan orang tua (Asmuni, 2020). Berdasarkan kondisi di atas, belum ada kajian mendalam tentang dampak positif dan negative pembelajaran jarak kauh di masa pandemi COVID-19. Tujuan penelitian ini adalah untuk menganalisis dampak positif dan negatif pembelajaran jark jauh di masa pandemi COVID-19.

\section{Metode}

Metode yang digunakan dalam penelitian ini adalah kualitatif dengan pendekatan deskriptif untuk memperoleh informasi mengenai dampak positif dan negatif pembelajaran jarak jauh di masa pandemi COVID-19. Dalam penelitian kualitatif istilah populasi tidak digunakan, oleh karena itu penelitian ini menggunakan istilah unit analisis sebagai subjek kajian (Herlina \& Suherman, 2020). Populasi penelitian ini adalah semua mahasiswa di Universitas Tabanan. Populasi penelitian berjumlah 10 mahasiswa. Pengambilan sampel dalam penelitian ini dilakukan dengan cara random sampling dengan jumlah sampel 5 . 
Instrumen pengumpulan data menggunakan wawacara menggunakan pedoman wawancara, teknik analisis data menggunakan analisis kualitatif. Penelitian ini dilakukan secara mendalam dengan wawancara. Wawancara dilakukan secara online. Meskipun online, penulis akan melakukan penelitian secara mendalam. Teknik analisis data dalam penelitian ini adalah teknik analisis sebelum berada di lapangan dan analisis model Miles dan Huberman.

\section{Hasil dan Pembahasan}

Pada era pandemi covid-19 mahasiswa Universitas Tabanan melakukan physical distancing dengan melakukan proses pembelajaran dirumah. Proses pembelajaran dengan metode pembelajaran jarak jauh secara menyeluruh. Bagi mahasiswa, pembelajaran daring merupakan pengalaman yang baru. Kondisi ini mengakibatkan mahasiswa melakukan adaptasi dengan metode pembelajaran. Berdasarkan hasil wawancara yang telah dilakukan pada mahasiswa Universitas Tabanan. Dalam pelaksanaan pembelajaran daring pada masa pandemi Covid-19 terdapat beberapa hambatan dalam pelaksanaannya. Pertama, jaringan tidak memadai. Hal ini disebabkan beberapa mahasiswa tinggal di daerah pedesaan yang jaringan internet kurang stabil. Kedua, mahasiswa kurang paham dengan materi pembelajaran. Hal ini dikarenakan beberapa dosen kurang menjelaskan materi secara mendalam sehingga mahasiswa kurang paham dengan materi yang disampaikan oleh dosen, selain itu dosen hanya memberikan materi dalam bentuk format file.

Ketiga, mahasiswa merasa kurang semangat mengikuti pembelajaran daring Hal ini dikarenakan akses internet yang tidak stabil, materi selama pembelajaran kurang dipahami, adanya gangguan-gangguan dari lingkungan sehingga mahasiswa tidak minat belajar mereka berkurang untuk mengikuti pembelajaran daring. Keempat, keterbatasan fasilitas dalam pembelajaran daring menyulitkan mahasiswa. Hal ini dikarenakan biaya laptop cukup mahal selain itu keterbatasan mahasiswa menggunakan aplikasi pembelajaran yang belum pernah digunakan sama sekali. Kelima, kuota internet mahal. Sebagian beranggapan sudah tidak ada permasalahan dengan kuota internet karena Kementrian Pendidikan dan Kebudayaan (Kemendikbud) sudah memberikan bantuan kuota internet gratis. Namun hasil wawancara menunjukkan beberapa mahasiswa belum mendapatkan, sehingga mahasiswa masih membeli kuota untuk menunjang pembelajaran daring

Pandemi ini mengakibatkan proses pembelajaran menjadi sangat terganggu, proses pembelajaran yang biasanya dilaksanakan dengan tatap muka langsung antara guru dan peserta didik di kelas selama pandemi pembelajaran berubah menjadi pembelajaran daring. Proses pembelajaran daring memerlukan sebuah media pembelajaran untuk mengefektifkan pembelajaran. Pembelajaran daring menjadi sebuah inovasi pendidikan yang melibatkan unsur teknologi informasi dalam pembelajaran. Ada berbagai macam media pembelajaran yang dapat menunjang kegiatan pembelajaran daring seperti WhatsApp, google classroom, quizizz, dan youtube agar menjadi efektif (Daheri et al., 2020; Permata \& Bhakti, 2020; Santosa et al., 2020; Setiyani et al., 2020; Widyantara \& Rasna, 2020). Pembelajaran daring memberikan manfaat dalam membantu menyediakan akses belajar bagi semua orang, sehingga menghapus hambatan secara fisik sebagai faktor untuk belajar dalam ruang lingkup kelas.

Pelaksanaan pembelajaran daring berdampak negatif terhadap hasil belajar mahasiswa, sebagian mahasiswa menyatakan bahwa selama pembelajaran daring dilaksanakan hasil belajar menurun. Hal ini disebabkan materi yang disampaikan dosen dipahami sangat kurang daripada pembelajaran tatap muka. Selain itu, minat belajar mahasiswa menjadi berkurang karena berbagai kendala yang dihadapi seperti jaringan internet tidak stabil, serta adanya gangguan-gangguan dari lingkungan sehingga mahasiswa malas belajar karena merasa terganggu. Fasilitas menjadi sangat penting untuk kelancaran 
proses pembelajaran, seperti laptop, komputer ataupun handphone yang akan memudahkan pembelajaran secara daring (Purwanto, 2020). Mahasiswa juga terasa terbebani karena sebagian dosen memberikan tugas di luar jam perkuliahan serta mengganti jadwal perkuliahan secara mendadak.

Pembelajaran daring tidak hanya berdampak negatif terhadap mahasiswa, namun berdampak positif terhadap mahasiswa seperti setelah dilaksanakannya pembelajaran daring proses pembelajaran tetap dapat berjalan meskipun dalam situasi pandemic COVID-19 walaupun dalam pelaksanaannya terdapat banyak kendala setidaknya mahasiswa masih dapat merasakan yang namanya sekolah. Pembelajaran daring juga membuat mahasiswa merasa lebih bebas atau santai dan dapat melakukan aktivitas lain saat mengikuti perkuliahan. Hal ini dapat dimanfaatkan oleh mahasiswa dengan berbagai aktivitas positif. Pembelajaran daring juga membuat mahasiswa lebih mandiri. Hal ini terjadi karena selama pembelajaran daring dosen hanya memberikan materi dengan singkat melalui file sehingga mengharuskan mahasiswa untuk mandiri dalam mencari penjelasan dari materi yang diberikan oleh dosen, sehingga dilaksanakan pembelajaran daring menuntut untuk mandiri.

Pembelajaran daring dinilai lebih parktis dan santai. Praktis karena dapat memberikan tugas setiap saat dan pelaporan tugas setiap saat dan lebih fleksibel berarti dilakukan kapanpun dan dimanapun. Pembelajaran daring menyebabkan waktu yang lebih fleksibel bagi mahasiswa yang berada di luar rumah dan bisa menyesuaikan waktu untuk belajar. menghemat waktu dan dapat dilakukan kapan saja. Semua siswa dapat mengaksesnya dengan mudah, artinya dapat dilakukan dimana saja. Penyampaian informasi lebih cepat dan bisa menjangkau banyak siswa. Lebih praktis dan memudahkan dalam pengambilan nilai pengetahuan terutama bila memakai Google Form. Jika menggunakan Google Form, nilai bisa langsung diketahui sehingga siswa lebih tertarik dalam mengerjakan tugas. Selain itu siswa juga dimudahkan dalam mengerjakannya. Siswa tinggal memilih pilihan jawaban yang dianggap benar dengan meng-klik pilihan jawaban yang dimaksud. Dosen dan mahasiswa memperoleh pengalaman baru terkait pembelajaran daring (Anugrahana, 2020).

Banyak penelitian yang dilakukan selama pembelajaran daring. Pembelajaran daring di SD dapat terlaksana dengan cukup baik, hal ini terlaksana apabila adanya kerjasama antara kepala sekolah, guru, dan orang tua dalam pelaksanaan belajar dari rumah (Dewi, 2020). Temuan penelitian lain tentang efektivitas pembelajaran daring pada mata kuliah Pendidikan Agama Islam dalam situasi pandemi Covid-19 masuk dalam kategori baik (Alvianto, 2020). Pembelajaran media daring di SMPIT dapat berjalan dengan baik, namun guru dan siswa tetap mengalami kesulitan dalam berinteraksi dan mengakses situs pembelajaran diinternet (Sofralda, Suci \& Atika Latifa, 2019). Temuan lain menyatakan pelaksanaan pembelajaran daring dikatakan kurang efektif karena memiliki beragam problematika yang dialami guru, peserta didik, dan orang tua (Asmuni, 2020). Pelaksanaan pembelajaran daring memungkinkan mahasiswa dan dosen melaksanakan perkuliahan dari rumah masing-masing (Mauludy, 2020). Mahasiswa dapat mengakses materi perkuliahan dan mengirim tugas yang diberikan dosen tanpa harus bertemu secara fisik di kampus.

Berdasarkan hal hasil penelitian tentang pembelajaran jarak jauh memberikan dampak positif dan negatif pada pembelajaran jarak jauh menunjukkan hasil bahwa pembelajaran jarak jauh kurang efektif. Hal isi dikarenakan masih banyak kendala yang dihadapi mahasiswa dibandingkan mahasiswa efektifnya pembelajaran daring. Saat ini. belum ada kajian mendalam tentang dampak negative dan positif selama pembelajaran jarak jauh.

\section{Simpulan}

Pembelajaran daring memberikan dampak positif dan negatif selama proses pembelajaran. Hal ini terlihat dari berbagai kendala dan kelebihan yang dimiliki pembelajaran jarak jauh. Dampak negative pembelajaran jarak jauh yaitu jaringan tidak 
memadai, mahasiswa kurang paham dengan materi pembelajaran, mahasiswa merasa kurang semangat mengikuti pembelajaran daring, keterbatasan fasilitas dalam pembelajaran daring menyulitkan mahasiswa dan kuota internet mahal. Dampak positif dari pembelajaran jarak jauh yaitu pembelajaran daring lebih parktis dan santai. penyampaian informasi lebih cepat dan bisa menjangkau banyak mahasiswa, siswa lebih tertarik dalam mengerjakan tugas, dosen dan siswa memperoleh pengalaman baru terkait pembelajaran daring. Hasil penelitian ini diharapkan dapat menjadi bahan evaluasi berbagai pihak dalam menyelenggarakan pembelajaran daring di perguruan tinggi, penelitian ini juga diharapkan dapat menjadi bahan kajian bagi peneliti lain dalam menganalisis dan mengembangkan motivasi belajar mahasiswa dalam pembelajaran daring pada masa darurat di masa yang akan datang.

\section{Daftar Rujukan}

Alvianto, A. (2020). Efektivitas Pembelajaran Daring Pada Mata Kuliah Pendidikan Agama Islam Dalam Situasi Pandemi Covid-19. TA'DIBUNA: Jurnal Pendidikan Agama Islam, 3(2), 13. https://doi.org/10.30659/jpai.3.2.13-26.

Anugrahana, A. (2020). Hambatan, Solusi dan Harapan : Pembelajaran Daring Selama Masa Pandemi Covid-19 Oleh Guru Sekolah Dasar. Jurnal Pendidikan Dan Kebudayaan, 10(3), 282-289. https://doi.org/10.24246/j.js.2020.v10.i3.p282-289.

Asmuni, A. (2020). Problematika Pembelajaran Daring di Masa Pandemi Covid-19 dan Solusi Pemecahannya. Jurnal Paedagogy, 7(4), 281. https://doi.org/10.33394/jp.v7i4.2941.

Daheri, M., Juliana, J., Deriwanto, D., \& Amda, A. D. (2020). Efektifitas WhatsApp sebagai Media Belajar Daring. Jurnal Basicedu, 4(4), 775-783. https://doi.org/10.31004/basicedu.v4i4.445.

Dewi, W. A. F. (2020). Dampak COVID-19 Terhadap Implementasi Pembelajaran Daring Di Sekolah Dasar. Jurnal Ilmu Pendidikan, 2(1), 55-61. https://doi.org/https://edukatif.org/index.php/edukatif/index.

Fifit Humairoh, Achmad Supriyanto, B. (2016). Implementasi Supervisi Klinis Dalam Meningkatkan. Teori, Penelitian, Dan Pengembangan, 1(12), 2277-2280. https://doi.org/10.31004/edukatif.v2i1.77.

Herliandry, Devi ., N. M. E. S. H. K. (2020). Pembelajaran Pada Masa Pandemi Covid-19. Jurnal Pendidikan Teknologi, 22(1), 65-69. https://doi.org/10. 21009/jtp.v22i1.15286.

Herlina, H., \& Suherman, M. (2020). Potensi Pembelajaran Pendidikan Jasmani Olahraga Dan Kesehatan (Pjok) Di Tengah Pandemi Corona Virus Disease (Covid)-19 Di Sekolah Dasar. Tadulako Journal Sport Sciences And Physical Education, 8(1), 1-7. http://jurnal.untad.ac.id/jurnal/index.php/PJKR/article/view/16186.

Khurriyati, Y., Setiawan, F., \& Mirnawati, L. B. (2021). Dampak Pembelajaran Daring Terhadap Hasil Belajar Siswa Mi Muhammadiyah 5 Surabaya. Jurnal Ilmiah Pendidikan Dasar, 8(1), 91. https://doi.org/10.30659/pendas.8.1.91-104.

Krisdiana, I., Apriandi, D., \& Setiansyah, R. K. (2014). Analisis Kesulitan Yang Dihadapu Oleh Guru Dan Peserta Didik Sekolah Menengah Pertama Dalam Implementasi Kurikulum 2013 Pada Mata Pelajaran Matematika (Studi Kasus Eks-Karesidenan Madiun). JIPM (Jurnal Ilmiah Pendidikan Matematika), 3(1). https://doi.org/10.25273/jipm.v3i1.492.

Maria Kristina Ota, Ana Maria Gadi Djou, F. F. N. (2021). Problematika Pembelajaran Daring Siswa Kelas Vii Smpn. Jurnal Pengabdian Masyarakat, 2(1), 74-81. https://doi.org/10.37478/mahajana.v2i1.769.

Mauludy, N. B. (2020). Dampak Covid-19 Terhadap Penerapan "Belajar Daring” Pada Siswa Luar Biasa Di SD Bandar Kidul 2 Kota Kediri. Prosiding Seminar Nasional, 244247. 
Nurkholis. (2020). Dampak Pandemi Novel-Corona Virus Disiase (Covid-19) Terhadap Psikologi Dan Pendidikan Serta Kebijakan Pemerintah. Jurnal PGSD, 6(1), 39-49. https://e-journal.umc.ac.id/index.php/JPS.

Pakpahan, R., \& Fitriani, Y. (2020). Analisa Pemafaatan Teknologi Informasi Dalam Pemeblajaran Jarak Jauh Di Tengah Pandemi Virus Corona Covid-19. JISAMAR (Journal of Information System, Applied, Management, Accounting and Researh), 4(2), 30-36. http://journal.stmikjayakarta.ac.id/index.php/jisamar/article/view/181.

Permata, A., \& Bhakti, Y. B. (2020). Keefektifan Virtual Class dengan Google Classroom dalam Pembelajaran Fisika Dimas111a Pandemi Covid-19. JIPFRI (Jurnal Inovasi Pendidikan Fisika Dan Riset Ilmiah), 4(1), 27-33. https://doi.org/10.30599/jipfri.v4i1.669.

Purwanto, A. (2020). Studi Eksploratif Dampak Pandemi COVID-19 Terhadap Proses Pembelajaran Online di Sekolah Dasar. Journal Education, Psycology, Councelling, 2(1). https://ummaspul.e-journal.id/Edupsycouns/article/view/397.

Putria, H. (2020). Analisis Proses Pembelajaran Dalam Jaringan (DARING) Masa Pandemi COVID-19 pada Guru Sekolah Dasar. Jurnal BASICEDU, 4(4), 861-872. https://doi.org/10.31004/basicedu.v4i4.460.

Rigianti, H. A. (2020). Kendala Pembelajaran Daring Guru Sekolah Dasar Di Kabupaten Banjarnegara. Jurnal Elementary School, 7(2), 297-302. https://doi.org/10.31316/esjurnal.v7i2.768.

Santosa, F. H., Negara, H. R. P., \& Samsul Bahri. (2020). Efektivitas Pembelajaran Google Classroom Terhadap Kemampuan Penalaran Matematis Siswa. Jurnal Pemikiran Dan Penelitian Pendidikan Matematika (JP3M), 3(1), 62-70. https://doi.org/10.36765/jp3m.v3i1.254.

Setiawan, W. \& D. Y. (2020). Dampak Pandemi COVID-19 Terhadap Kegiatan Pembelajaran Online di STMIK Komputama Majenang. Teknologi Dan Bisnis, 2(2), 16-25. https://doi.org/10.37087/jtb.v2i2.21.

Setiyani, S., Fitriyani, N., \& Sagita, L. (2020). Improving student's mathematical problem solving skills through Quizizz. JRAMathEdu (Journal of Research and Advances in Mathematics Education), 5(3), 276-288. https://doi.org/10.23917/jramathedu.v5i3.10696.

Sofralda, Suci \& Atika Latifa, A. M. P. (2019). Analisis Penerapan Metode Pembelajaran Jarak Jauh Menggunakan Media Daring Di SMPIT Al-Islah Cibinong. Jurnal Ilmiah Islam, 2(1), 11-17. http//jurnal.iuqibogor.ac.id.

Sohrabi, C., Alsafi, Z., O’Neil, N., Khan, M., Kerwan, A., Al-Jabir, A., . . Aghad, R. (2020). World Health Organization declares global emergency: A review of the 2019 novel coronavirus (COVID-19). International Journal of Surgery, 71-76. https://doi.org/10.1016/j.ijsu.2020.02.034.

Talevi, D., Socci, V., Carai, M., Carnaghi, G., Faleri, S., Trebbi, E., Bernardo, A. D. I., Capelli, F., \& Pacitti, F. (2020). Mental health outcomes of the CoViD-19 pandemic Gli esiti di salute mentale della pandemia di CoViD-19. Riv Psichiatr, 55(3), 137144. https://doi.org/10.1708/3382.33569.

Widyantara, I., \& Rasna, I. (2020). Penggunaan Media Youtube Sebelum Dan Saat Pandemi Covid-19 Dalam Pembelajaran Keterampilan Berbahasa Peserta Didik. Jurnal Pendidikan Dan Pembelajarna Bahasa Indonesia, 9(2).

Zhang, W., Wang, Y., Yang, L., \& Wang, C. (2020). Suspending Classes Without Stopping Learning: China's Education Emergency Management Policy in the COVID-19 Outbreak. Journal of Risk and Financial Management, 13(3), 55. https://doi.org/10.3390/jrfm13030055. 